Original Contribution

\title{
STUDY ON SOME BIOLOGCAL PERFORMANCE OF MULE DUCKS WITH DISCONTINUED PROBIOTIC TREATMENT
}

\author{
D. Penkov ${ }^{1 *}$, M. Petkova ${ }^{1}$, P. Petkova ${ }^{2}$ \\ ${ }^{1}$ Agricultural University, Plovdiv, Bulgaria \\ ${ }^{2}$ HL-TopMix, Sliven, Bulgaria
}

\begin{abstract}
Aim: To establish the effect of the new for Bulgaria probiotic ProMixAn Forte ${ }^{\circledR}$ in discontinued treatment of mule ducks for the first 28 days, when reared up to 72 days of age. Material and Methods: A research study was carried out with two groups of 50 female ducks each. The ducks were reared under a three-phase feeding regime, given the same feed, the forage of the experimental group being supplemented with the probiotic from 1 to 28 days of age (starter), after which the probiotic was stopped. Results: After 14 days, the experimental ducks showed significantly higher weight gain $(5 \%-9 \%$ in average for the separate periods), the tendency continuing for 15 days after stopping the probiotic (43 days of age), after which the weight gain decreased by more than 4 times compared to the control group. After 56-th day of age, the experimental ducks had a higher growth rate than the control, but they could not compensate for the lag. At the end of the period, the experimental fowl showed $17 \%$ lower final live weight compared to the untreated. The results of the feed conversion ratio (FCR) to produce a $\mathrm{kg}$ of live weight were analogous, but opposite in value. FCR was 8 to 13\% lower in the experimental birds from 14 to 43 days of age, over 4.5 times higher from 43 to 57 days and $40 \%$ lower from 57 to 72 days, thus the negative results in the previous period were compensated. The differences in the separate periods were statistically significant.

Conducted microbiological examination of caecum and fresh droppings showed that on the day of discontinuing the probiotic treatment, the ratio of lactic acid to coli bacteria in the experimental group was in favour of the genus Lactobacillus, while 4 weeks later it changed in favour of the coli bacteria.
\end{abstract}

Key words: bacterial ratio, feed conversion ratio, growth, mule ducks, probiotics

\section{INTRODUCTION}

The use of probiotics in the control of intestinal microflora in poultry has been increasingly applied since feed antibiotics were banned in the European Union (1).

Probiotics are live microorganisms in a latent state that are activated in the gastrointestinal tract (2), creating favourable conditions for nutrient intake (3-5) and limiting the development of pathogenic and conditionally pathogenic bacteria $(6,7)$. Since those microorganisms are naturally occurring in nature, they are not dangerous to the health of the animals receiving them, and what is more, they increase their productive and economic

\footnotetext{
*Correspondence to: Dimo Penkov, Agricultural University - 4000 Plovdiv, Bulgaria, $12 \mathrm{D}$. Mendeleev Str., dimopenkov@gmail.com
}

performance, without affecting the safety and quality of the animal products for human consumption (8-12).

The positive effect of probiotics containing bacteria of the Lactobacillus genus has been established for a long time when monitoring the physiological and productive characteristics of Muscovy and mule ducks $(13,14)$. In the present study, the new for Bulgaria probiotic ProMixAn Forte ${ }^{\circledR}$ was used.

Discontinuing probiotic treatment during the growth period of the ducks could affect bacterial ratios in the intestinal tract, which could influence the health and productivity.

The aim of the present study was to determine the effect of the discontinued probiotic treatment during the rearing period of mule ducks on their growth and on the feed conversion ratio. 


\section{MATERIAL AND METHODS}

A farm experiment was carried out with 2 groups of 50 female mule ducks each (white variety), reared up to 72 days of age under a three-phase feeding regime.

The compound forages contained (in $1 \mathrm{~kg}$ of feed, $14 \%$ moisture content):

Starter (1 - 28 days of age): Metabolizable energy - 12 MJ, Crude protein - 18.5\%, Lysine $-1 \%$, Methionine+cystine $-0.75 \%$, Calcium - 1\%, Avail. phosphorus - 0.5\%, particle size of the granules $3 \mathrm{~mm}$.

Grower $(29-57$ day of age: Metabolizable energy - $12 \mathrm{MJ}$, Crude protein - $17.5 \%$, Lysine $-0.8 \%$, Methionine+cystine $-0.55 \%$, Calcium $-0.9 \%$, Avail. phosphorus $-0.35 \%$, particle size of the granules $4 \mathrm{~mm}$.

Finisher (58 - 72 days of age: Metabolizable energy - 12 MJ, Crude protein - $16.5 \%$, Lysine $-0.75 \%$, Methionine+cystine $-0.50 \%$, Calcium $-0.9 \%$, Avail. phosphorus $-0.30 \%$, particle size of the granules $6 \mathrm{~mm}$.

Poultry were fed ad libitum, offering them forage after they had consumed all the previous feed.

The feed of the control and the experimental group was the same, but the probiotic ProMixAn Forte ${ }^{\circledR}$ obtained by spray drying, was added to the starter for the experimental group from the beginning to 28 days of age at the rate of $400 \mathrm{~g} /$ ton of feed.

ProMixAn Forte ${ }^{\circledR}$ probiotic is new for Bulgaria and contains the following major bacterial strains: Lactobacillus bulgaricus, Lactobacillus lactis, Lactobacillus acidophilus, Lactobacillus helveticus, Streptococcus thermophilus, Enterococcus faecium, with a guaranteed total number of $4.5 \times 10^{9} \mathrm{cfu}$ per $\mathrm{g}$.
The live weight of the ducks in both groups was measured every 7 days from the $1^{\text {st }}$ to $28^{\text {th }}$ day of the experiment with scales to the nearest $1 \mathrm{~g}$ and every 14 days from the $29^{\text {th }}$ day to the end of the weighing test to the nearest $3 \mathrm{~g}$.

The weight gain was defined as the difference between the current and the previous measurement.

Feed conversion ratio was determined as the amount of feed consumed between the two measurements, divided by the weight gain in the group over the same period.

During the experimental period duck losses were not reported.

The results were processed by variation statistics methods using the Biostatistics-Excel programme.

On $28^{\text {th }}$ and $56^{\text {th }}$ days from the beginning of the study, 2 samples of caecum and 2 samples of fresh droppings were collected from the experimental and the control groups, which were immediately cooled to $4^{\circ} \mathrm{C}$. The samples were microbiologically examined for the presence of bacteria of the genus Lactobacillus and Escherichia. Lactic acid bacteria were cultured on MRS medium (DeMan, Rogosa and Sharpe agar, Merck LTD, USA) at $30^{\circ} \mathrm{C}$. Samples for E. coli tests were diluted in physiological solution and inoculated on MacConkey agar, followed by incubation for $18-24 \mathrm{~h}$ at $37^{\circ} \mathrm{C}$.

\section{RESULTS AND DISCUSSION}

The average live weight values in the starter and grower periods of the control and the experimental groups up to the age of 43 days are presented in Table 1 (the probiotic was given up to 28 days of age).

Table 1. Live weight of the ducks at the studied ages $(g) *$

\begin{tabular}{ccccc}
\hline Days of age & \multicolumn{2}{c}{ Control group } & \multicolumn{2}{c}{ Experimental group } \\
& $X$ & $S D$ & $X$ & SD \\
\hline $1^{\text {st }}$ day of age & 44.45 & 0.51 & 45.67 & 0.56 \\
$28^{\text {th }}$ day of age & $1150.85^{\mathrm{a}}$ & 19.70 & $1209.24^{\mathrm{a}}$ & 21.57 \\
$43^{\text {rd }}$ day of age & $1882.75^{\mathrm{a}}$ & 34.36 & $2077.96^{\mathrm{a}}$ & 46.80 \\
$57^{\text {th }}$ day of age & $3018.47^{\mathrm{a}}$ & 46.44 & $2349.18^{\mathrm{a}}$ & 45.21 \\
$72^{\text {nd }}$ day of age & $3213.06^{\mathrm{a}}$ & 51.84 & $2684.08^{\mathrm{a}}$ & 41.56 \\
\hline
\end{tabular}

Note: ${ }^{\mathrm{a}-\mathrm{a}}$ stat. significant by rows $\mathrm{P}<0.05$

During the starter period, up to 28 days of age, the probiotic-treated ducks gained in weight more intensively and at 28 days of age their average live weight was 59 grams or $5.13 \%$ higher than that of the control group. The results are comparable to those obtained in our previous studies with a similar probiotic (13). Despite the discontinuation of the probiotic, its 
positive effect persisted for about 15 more days, the average live weight of the experimental group being by $95 \mathrm{~g}$ or $5.05 \%$ higher than the control group at the next weighing. After 57 days of age, a relatively sharp decrease in growth capacity of the experimental ducks was reported, and, on $57^{\text {th }}$ day of the experiment (29 days after stopping the probiotic), the live weight of the experimental ducks was significantly lower by an average of $668 \mathrm{~g}$ or about $28 \%$ compared to the control group. Data from previous studies of the authors $(13,15,16)$ indicated that the control ducks continued to gain in weight within their biological capacity, while there was a sharp decrease in the growth rate of the treated fowl, which obviously failed to overcome the negative effect after discontinuation of the probiotic administration and the changes in the bacterial ratio in their digestive systems.

Data of comparing the growth rate of the control and the experimental ducks completely confirmed the results obtained from the comparison of the live weight during the reported periods (Figure 1).

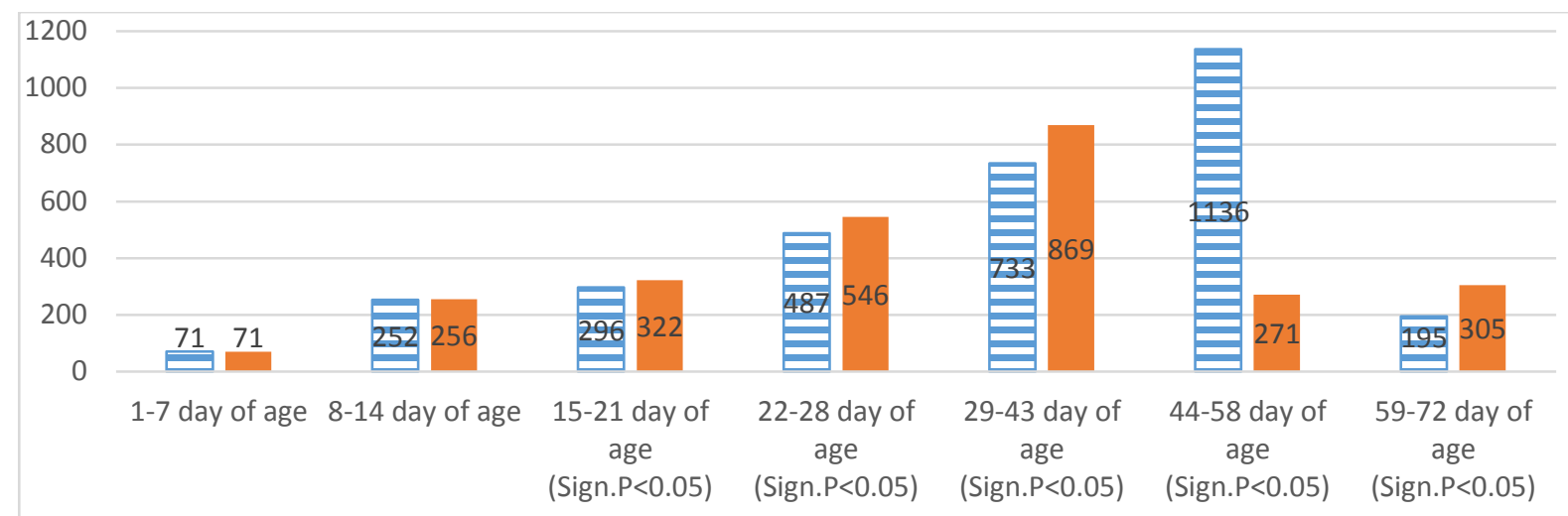

Figure 1. Average body weight gain during the studied periods

In the first and second weeks, the experimental ducks did not show significantly higher weight gain, which is consistent with the opinion that the effect of probiotics on productive performance is relatively slow. After 14 days, the effect was already statistically significant in favour of the probiotic-treated group and it persisted for up to 14 days after discontinuation of the treatment. The period between 43 and 57 days of age (14-28 days after stopping the probiotic) was the most critical in terms of growth retention in the experimental ducks, the decrease in the growth rate being more than 4.5 times compared to the control group. During the last studied period (59-72 days of age), the experimental group had a significantly higher growth than the control, but it could not compensate for the lag in weight gain for the whole experimental period (Table 1). However, it can be concluded that 25-30 days after stopping the probiotic, the fowl restored their growth capacity, most likely stabilizing the ratio between the different types of bacteria in their digestive system.

In order to confirm that fact, a comparative study was carried out on the ratios of Lactobacillus and Escherichia bacteria in the guts and excreted droppings of the representatives of the experimental and control groups in the different periods (Table 2).

For the ducks receiving the probiotic up to 28 days, the ratio between the studied bacteria on $28^{\text {th }}$ day of the trial was apparently in favour of the genus Lactobacillus both in the intestine and in the fresh droppings, whereas 28 days after stopping the probiotic, the ratio sharply changed in favour of the genus Escherichia. In the control group, the ratios between the two genera were relatively the same during the studied periods in both the intestine and the freshly excreted droppings. 
Table 2. Ratio of Lactobacillus and Escherichia bacteria in the intestines and droppings of the ducks:

\begin{tabular}{|c|c|c|c|c|}
\hline \multirow{2}{*}{$\begin{array}{c}\text { Groups/ } \\
\text { Bacteria species }\end{array}$} & \multicolumn{2}{|c|}{ Control group } & \multicolumn{2}{|c|}{ Experimental group } \\
\hline & 28 days of age & 56 days of age & 28 days of age & 56 days of age \\
\hline $\begin{array}{l}\text { Escherichia coli- } \\
\text { caecum - cfu/g* }\end{array}$ & $1.5 \times 10^{5}$ & $2.5 \times 10^{5}$ & $<0.1 \times 10^{5}$ & $2.5 \times 10^{5}$ \\
\hline $\begin{array}{l}\text { Escherichia coli- } \\
\text { fresh excrements - } \\
\text { cfu/g* }\end{array}$ & $1.5 \times 10^{5}$ & $1.5 \times 10^{5}$ & $<0.1 \times 10^{5}$ & $2.5 \times 10^{5}$ \\
\hline $\begin{array}{l}\text { Lactobacillus sp.- } \\
\text { caecum - cfu/g** }\end{array}$ & $>10 \times 10^{5}$ & $2.1 \times 10^{5}$ & $8.5 \times 10^{5}$ & $0.95 \times 10^{5}$ \\
\hline $\begin{array}{l}\text { Lactobacillus sps - } \\
\text { fresh excrements- } \\
\text { cfu/g** }\end{array}$ & $1.65 \times 10^{5}$ & $1.2 \times 10^{5}$ & $5.23 \times 10^{5}$ & $0.9 \times 10^{5}$ \\
\hline
\end{tabular}

Table 3 shows the feed conversion ratio to produce $1 \mathrm{~kg}$ of live weight over the studied periods.

Table 3. Feed conversion ratio of the mule ducks by periods $\left(\mathrm{kg}^{*} \mathrm{~kg} \mathrm{~g}^{-1}\right)$

\begin{tabular}{ccccc}
\hline Period from... to (days) & \multicolumn{2}{c}{ Control group } & \multicolumn{2}{c}{ Experimental group } \\
& $X$ & SD & $X$ & SD \\
\hline $1-28$ & $4.14^{\mathrm{a}}$ & 0.42 & $3.73^{\mathrm{a}}$ & 0.37 \\
$29-43$ & $7.96^{\mathrm{a}}$ & 0.98 & $6.58^{\mathrm{a}}$ & 0.65 \\
$44-57$ & $4.28^{\mathrm{a}}$ & 0.95 & $16.22^{\mathrm{a}}$ & 1.23 \\
$58-72$ & $39.57^{\mathrm{a}}$ & 1.42 & $21.65^{\mathrm{a}}$ & 1.18 \\
$1-72$ & 13.99 & 1.58 & 12.05 & 2.49 \\
\hline
\end{tabular}

Note: ${ }^{\mathrm{a}-\mathrm{a}}$ - stat. significant by rows $\mathrm{P}<0.05$

In the starter period, the probiotic-treated group had a significantly lower feed conversion ratio compared to the control group. Despite the discontinuation of the probiotic, its post-effect on the lower feed conversion ratio per $1 \mathrm{~kg}$ of weight gain was maintained for up to 43 days from the beginning of the study. From $43^{\text {rd }}$ to $57^{\text {th }}$ day, the experimental group had no problems with the appetite and ate intensively, but the difference in the feed conversion rate (almost 4 times higher compared to the control group) could be explained by the fact that the ducks did not gain in weight with the necessary intensity. Apparently, nutrient consumption was mainly a compensation for the dramatically changed ratio of Lactobacillus to Escherichia. Such a rapid change under different bacteria species is accompanied by digestive disorders and poor feed utilization. In the next days to the end of the experiment the experimental ducks compensated the feed conversion ratio, and that compensation was enough for a comparative equalization in both of the FCR for the whole growing period.
Comparing data of the live weight obtained in the present study with those obtained by (14, 17) $-4.68 \mathrm{~kg}$ for probiotic-treated and $4.86 \mathrm{~kg}$ for control fowl, respectively, it could be seen that for the first 28 days the feed conversion ratios were close, what is more, even in favour of our data. From $29^{\text {th }}$ to $43^{\text {rd }}$ day, according to our data, they were about $25 \%$ higher than the cited results and after $43^{\text {rd }}$ day the ducks of the present study showed a very high FCR per unit of weight gain.

The female chickens have an intensive growth up to 50-55 days of age and after that they have lover possibilities to compensate the eventual growth retardation at a younger age (18). In our investigation we have obtained, that the stress from the probiotic's discontinuation in the period of maximum growth cannot be compensated.

\section{CONCLUSIONS}

When using ProMixAn Forte ${ }^{\circledR}$ probiotic at the rate of $400 \mathrm{~g} /$ ton of feed in the starter (1-28 days of age) for female mule ducks, there was 
about 5\% significantly higher weight gain and lower feed conversion ratio per unit of weight gain up to $28^{\text {th }}$ day from the beginning of the trial.

The positive effect of discontinued probiotic use on $28^{\text {th }}$ day was maintained up to 43 days after the beginning of the study, or about 14 days after stopping it, the results reported for both productive characteristics being higher and statistically significant in favour of the probiotic-treated fowl.

After 43 days (14 days after stopping the probiotic) to day 57 there was a sharp deterioration in the performance of the experimental group, it lagging behind in growth rate about 4.5 times and having about 4 times higher FCR per $\mathrm{kg}$ of weight gain compared to the control.

From $57^{\text {th }}$ day until the end of the trial (72 days of age), the discontinued probiotic group compensated the lag in both characteristics, but the compensation was sufficient to overcome the negative effect in the feed conversion ratio. At the end of the experiment, the group with the discontinued probiotic had a lower live weight than the control ducks.

The microbiological tests of caecum and fresh droppings showed that on the day of stopping the probiotic, the ratio of lactic acid to coli bacteria in the experimental group was in favour of the genus Lactobacillus, while 4 weeks later it changed dramatically in favour of coli bacteria. In the control group, the ratios between the two bacterial genera did not differ significantly over the study periods.

\section{ACNOWLEDGEMENTS}

The research study was conducted with the logistical and financial support of: 1. Bulgarian Livestock Investment Company (www.blicbg.com); 2. Lactina LTD (www.lactina-ltd.com); DES 93 LTD (des93et@yahoo.com). HL-TopMix (https://hltopmix.com/bg).

\section{REFERENCES}

1. Regulation (EC) No. 1831/2003 of the European Parliament and of the Council of 22 September 2003, https://eurlex.europa.eu , legal-content , TXT , uri=CELEX:32003R1831.

2. Havenaer, R., Brink, B. T., Huis, J. H. H. and Fuller, R., Selection of strains for probiotic use. In: Probiotics: The Scientific
Basis (Ed. Fuller R.), Chapman and Hall, London, pp. 209-224, 1992.

3. Nahashon, S. N., Nakaue, H. S. and Mirosh, L. W., Performance of Single Comb White Leghorn layers fed with a live microbial during the growth and egg laying phases. Anim. Feed Sci. Technol., 57: 25-38, 1996.

4. Jin, L. Z., Ho, Y. W., Abdullah, A. M. and Jalaludin, S., Effects of Lactobacillus culture on the digestive enzymes in chicken intestine. Proc. $8^{\text {th }}$ Anim. Sci. Congress, Tokyo, Chiba, Japan, pp. 224-225, 1996.

5. Jin, L. Z., Ho, Y. W., Abdullah, A. M. and Jalaludin, S., Digestive and bacterial enzyme activities in broiler fed diets supplemented with Lactobacillus cultures. Poultry Sci., 79: 886-891, 2000.

6. Fuller, R., The importance of lactobacilli in maintaining normal microbial balance in the crop. Brit. Poultry Sci., 18: 85-94, 1977.

7. Ghadban, G., Kabakchiev, M. and Angelov, A., Efficacy of different methods of probiotic treatment in preventing infection of broiler chicks with Salmonella typhimurium and E. coli O7. Proc. $10^{\text {th }}$ EPC, June 21-26, vol. I, 305-310, 1998.

8. Schwab, C. G., Moore, J. J., Hoyt, P. M. and Prentice, J. L., Performance and caecal flora of calves fed nonviable Lactobacillus bulgaricus fermentation product. J. Dairy Sci., 63: 1414-1423, 1980.

9. Perdigon, G., Alvares, S., De Macias, M. E. N., Roux, M. E. and De Ruiz Hodalgo, The oral administration of lactic acid bacteria increase the mucosal intestinal immunity in response to enteropathogens. J. Food Protection, 53: 404-410, 1990.

10. Perdigon, G., Alvares, S., Rachid, M., Aguero, G. and Gobbato. N., Immune system stimulation by probiotics. J. Dairy Sci., 78: 1597-1606, 1995.

11. Rautava, S. and Isolauri, E., The development of gut immune responses and gut microbiota: Effects of probiotics in prevention and treatment of allergic disease. Curr. Issues Intest. Microbiol., 3: 15-22, 2002.

12. Grigorova, S., S. Surdjiiska, D. Stoyanov and M. Dimitrova, Influence of probiotic Lactina on the productivity of layers, Bulgarian Journal of Agricultural Science, 10: 637-642, 2004.

13.Penkov D., V. Gerzilov, M. Nikolova and A. Genchev, Study on the effect of Lactina probiotic in nature friendly feeding of 
Muscovy ducklings. I. Growth capacities, Animal Science (BG), 4, 24-27, 2004.

14. Djouvinov, D., S. Boicheva, T. Simeonova and T. Vlaikova, Effect of feeding Lactina Probiotic on performance, some blood parameters and caecal microflora of mule ducklings, Trakia Journal of Sciences, Vol. 3, No. 2, 22-28, 2005.

15. Penkov, D. and T. Hristova, Investigation on the influence of Lactina-probiotic upon the energy and true digestibility of the amino acids of combined fodder by experiments with Muscovy ducks, Animal sciences (BG). 41, 6, 8-10, 2004.
PENKOV D., et al.

16. Penkov, D., M. Nikolova and V. Gerzilov, Study on the effect of Lactina probiotic in nature friendly feeding of Muscovy ducklings. II. Slaughter indexes and chemical composition of breast and thigh muscles, Scientific works - AU - Plovdiv, vol. 49, 29-36, 2004.

17. Petrov, P. and V. Gerzilov, Growth performance of mule ducklings during the different seasons, Agricultural Sciences, 14, 225-229, 2013.

18. Lesson, S., Summers, J.D. and Caston, L.J. Diet dilution and compensatory growth in boilers. Poultry Science 70: 867-873, 1991. 